\title{
Evaluation of commercial veterinary probiotics containing enterococci for transferrable vancomycin resistance genes
}

\author{
Ana Berreta \\ Washington State University \\ Rachel M Baumgardner \\ Washington State University \\ Jamie Jennifer Kopper ( $\square$ JKopper@iastate.edu ) \\ lowa State University College of Veterinary Medicine
}

\section{Research note}

Keywords: Antimicrobial resistance, enterococcus, vancomycin, probiotic

Posted Date: June 2nd, 2020

DOl: https://doi.org/10.21203/rs.3.rs-20668/v2

License: (c) (i) This work is licensed under a Creative Commons Attribution 4.0 International License.

Read Full License

Version of Record: A version of this preprint was published at BMC Research Notes on June 4th, 2020. See the published version at https://doi.org/10.1186/s13104-020-05114-1. 


\section{Abstract}

Objective: Vancomycin resistant enterococci (VRE) are of significant public health concern. The identification of VRE in livestock and food has increased. The objective of this study was to determine if the transferrable vancomycin resistance genes van $A$ and $\operatorname{van} B$ were present in probiotics marketed for use in animals that claimed to contain Enterococcus spp.

Results: Of the 40 products selected, Enterococcus spp. DNA was successfully extracted from 36 products. Of these 36 products with enterococcal DNA, $2(6 \%)$ had a PCR product consistent with vanA which was confirmed by sequencing. None of the products appeared to contain vanB.

\section{Introduction}

The development of antimicrobial resistance (AMR) is considered one of the greatest threats to public health [1,2]. Specifically, the development of vancomycin resistant enterococci (VRE) is of particular concern due to its association with significant morbidity and mortality in hospital acquired infections and few means to treat such infections [3]. Resistance in VRE is typically conferred by vanA or vanB genes, although other variants exist, both of which are transmissible by plasmids or transposons $[4,5]$.

Probiotics, defined as live micro-organisms that when administered in adequate amounts confer a health benefit to the host [6], are often considered "generally recognized as safe" within the United States of America (USA) meaning that they are exempt from regulatory testing by the Food and Drug Administration [7]. Thus, routine surveillance for AMR genes in commercial probiotics is not performed in the USA. Enterococcus spp. are frequently used in probiotics due to their reported potential to confer several health benefits to the host including restoration of normal microbiota following antimicrobial associated dysbiosis [8] and positive effects on the immune system [9]. However, the use of Enterococcus spp. in probiotics is controversial due to their association with nosocomial infections and potential to contain multiple AMR genes including vancomycin resistance genes $[10,11]$.

The objective of this study was to determine if the transferrable vancomycin resistance genes vanA and vanB were present in probiotics marketed for use in animals that claimed to contain Enterococcus spp. We hypothesized that commercially available veterinary probiotics containing enterococci would have the transferrable vancomycin resistance genes vanA and/or vanB.

\section{Materials And Methods}

Selection of Probiotics: A list of commercially available probiotics that claimed to contain at least one Enterococcus spp., were marketed for use in animals and available for purchase by owners was compiled using common online sources. A random number generator (www.random.org) was utilized to select 40 products for further evaluation. Products were purchased and stored according to the manufacturer's recommendations. 
DNA extraction from commercial probiotics: DNA was extracted from probiotics using one of several commercially available DNA extraction kits from QIAGEN (QIAGEN, Valencia, CA, USA) including the DNeasy PowerFood Microbial kit, DNeasy PowerSoil kit, DNeasy Blood and Tissue kit, QIAamp DNA Stool Mini kit and DNeasy PowerMax Soil kit. The kit utilized for each product is noted in Table 1. Due to the variability of probiotic substrates, multiple kits were utilized to find the best extraction method for each probiotic. DNA quantity and quality (i.e. A260:280 ratio) was assessed using NanoDrop ${ }^{\circledR}$ spectrophotometry (Thermofisher, Waltham, MA, USA). Extractions with the highest quantity and best purity were used for further analyses.

Extraction of DNA from positive control bacteria for AMR genes: Enterococcus avium containing the vanA gene obtained from the Center for Disease Control and FDA Antibiotic Resistance Isolate Bank (Atlanta, GA, USA) and Enterococcus faecalis containing vanB (ATCC®700802) obtained from the American Tissue Type and Culture (Manassas, VA, USA) were used as positive controls. Frozen cultures were propagated according to the suppliers' instructions. Subsequently, colonies were placed in $1.5 \mathrm{ml}$ TrisEDTA buffer and DNA was extracted using QIAGEN's DNeasy Ultraclean Microbial kit (QIAGEN, Valencia, CA, USA) according to the manufacturer's instructions. DNA concentration and quality were was assessed using NanoDrop ${ }^{\circledR}$ spectrophotometry (Thermofisher, Waltham, MA, USA).

Table 1: Extraction kits utilized for each product 


\begin{tabular}{|c|c|c|c|c|c|}
\hline Species & Product & Extraction Kit & $\begin{array}{l}\text { Ent PCR } \\
\end{array}$ & $\operatorname{van} A$ & $\operatorname{vanB}$ \\
\hline Bovine & $\begin{array}{l}1 \\
2 \\
3 \\
4 \\
5 \\
6 \\
7\end{array}$ & $\begin{array}{l}\mathrm{d} \\
\mathrm{c} \\
\mathrm{d} \\
\mathrm{e} \\
\mathrm{a} \\
\mathrm{a} \\
\mathrm{e}\end{array}$ & $\begin{array}{l}+ \\
+ \\
+ \\
+ \\
+ \\
+ \\
+\end{array}$ & $\begin{array}{l}- \\
- \\
- \\
- \\
- \\
- \\
-\end{array}$ & $\begin{array}{l}- \\
- \\
- \\
- \\
- \\
- \\
-\end{array}$ \\
\hline Camelid & 8 & $\mathrm{~b}$ & - & - & - \\
\hline Canine & $\begin{array}{l}9 \\
10 \\
11 \\
12 \\
13 \\
14 \\
15 \\
16 \\
17\end{array}$ & $\begin{array}{l}\mathrm{b} \\
\mathrm{a} \\
\mathrm{b} \\
\mathrm{a} \\
\mathrm{d} \\
\mathrm{c} \\
\mathrm{a} \\
\mathrm{a} \\
\mathrm{a}\end{array}$ & $\begin{array}{l}+ \\
+ \\
+ \\
+ \\
+ \\
+ \\
+ \\
+ \\
+\end{array}$ & $\begin{array}{l}- \\
- \\
- \\
- \\
- \\
+ \\
- \\
- \\
-\end{array}$ & $\begin{array}{l}- \\
- \\
- \\
- \\
- \\
- \\
- \\
- \\
-\end{array}$ \\
\hline Caprine & 18 & $\mathrm{~d}$ & + & + & - \\
\hline Equine & $\begin{array}{l}19 \\
20 \\
21 \\
22 \\
23 \\
24 \\
25 \\
26 \\
27 \\
28 \\
29 \\
30 \\
31\end{array}$ & $\begin{array}{l}d \\
\text { d } \\
\text { d } \\
\text { c } \\
\text { d } \\
\text { d } \\
\text { d } \\
\text { d } \\
\text { d } \\
\text { e } \\
\text { d } \\
\text { e } \\
\text { c }\end{array}$ & $\begin{array}{l}+ \\
+ \\
+ \\
- \\
- \\
+ \\
+ \\
+ \\
+ \\
+ \\
+ \\
+ \\
-\end{array}$ & $\begin{array}{l}- \\
- \\
- \\
- \\
- \\
- \\
- \\
- \\
- \\
- \\
- \\
- \\
-\end{array}$ & $\begin{array}{l} \\
- \\
- \\
- \\
- \\
- \\
- \\
- \\
- \\
- \\
- \\
- \\
-\end{array}$ \\
\hline Multiple* & 32 & $\mathrm{C}$ & + & - & - \\
\hline Feline & \begin{tabular}{|l}
33 \\
34 \\
35 \\
36 \\
37 \\
38 \\
39 \\
40
\end{tabular} & $\begin{array}{l}\mathrm{d} \\
\mathrm{a} \\
\mathrm{d} \\
\mathrm{a} \\
\mathrm{a} \\
\mathrm{b} \\
\mathrm{b} \\
\mathrm{a}\end{array}$ & $\begin{array}{l}+ \\
+ \\
+ \\
+ \\
+ \\
+ \\
+ \\
+\end{array}$ & $\begin{array}{l}- \\
- \\
- \\
- \\
- \\
- \\
- \\
-\end{array}$ & $\begin{array}{l}- \\
- \\
- \\
- \\
- \\
- \\
- \\
-\end{array}$ \\
\hline
\end{tabular}

Letters under the extraction kit column signify the QIAGEN ® (Valencia, CA USA) extraction kit utilized: (a) DNeasy PowerFood Microbial Kit, (b) DNeasy PowerSoil Kit, (c) DNeasy Blood and Tissue Kit, (d) QIAamp DNA Stool Mini Kit, (e) DNeasy PowerMax Soil Kit. PCR's marked as + were identified in that product PCR and for vanA and vanB the PCR product was confirmed to match the gene of interest by sequencing. Ent is indicative of Enterococcus spp. 
Bacterial DNA confirmation: The presence of bacterial DNA in each probiotic DNA extraction was confirmed using a bacterial 16S rRNA PCR as previously described (Table 2) [12] with the following modifications: amplification was performed by an initial denaturalization at $95^{\circ} \mathrm{C}$ for 3 minutes, then 25 cycles of denaturalization at $95^{\circ} \mathrm{C}$ for 30 seconds, annealing at $50^{\circ} \mathrm{C}$ for 1 minute, and extension at $72^{\circ} \mathrm{C}$ for 2 minutes. The final extension was performed at $72^{\circ} \mathrm{C}$ for 10 minutes, then the sample was held at $4^{\circ} \mathrm{C}$ until ready to be analyzed via gel electrophoresis. The PCR products were evaluated by electrophoresis in $2 \%$ agarose gel, stained with ethidium bromide and visualized to evaluate for a corresponding 994bp PCR product.

Detection of Enterococcus spp. by PCR: Probiotic DNA was evaluated for the presence of DNA from Enterococcus spp. using previously published primers (Table 2) and PCR protocols [13]. PCR products were evaluated by electrophoresis in $2 \%$ agarose gel, stained with ethidium bromide and visualized for an appropriately sized PCR product. DNA samples with an appropriately sized PCR product were considered positive for Enterococcus spp. DNA.

Validation of vanA and vanB PCRs: Previously published PCRs for vanA and $\operatorname{van} B$ [14] were used in this study (Table 2). The reactions were validated in our laboratory using DNA extracted from bacterial cultures with known vanA or vanB genes as described above. PCRs were confirmed to have DNA product of the expected size using gel electrophoresis. PCR products were confirmed to correspond with vanA and van $B$ sequences as described below.

Detection of vanA and vanB genes in probiotics via PCR: DNA from the probiotics with bacterial DNA were evaluated for the presence of van $A$ and $\operatorname{van} B$ genes using previously published PCRs as described and validated above. The PCR products were evaluated by electrophoresis in $2 \%$ agarose gel, stained with ethidium bromide and visualized for an appropriately sized PCR product. For products without a corresponding band of interest, the PCR was repeated with the same parameters using $10 \mu \mathrm{l}$ of the initial PCR as template. The second PCR was again evaluated by electrophoresis in $2 \%$ agarose gel, stained with ethidium bromide and visualized for an appropriately sized PCR product.

Sequencing of amplified AMR genes: Positive control and probiotic sample PCRs with appropriately sized PCR products were treated with ExoSAP-it reagent (Affymetrix Life Science Reagents, OH, USA) in accordance with the manufacturer's instructions. Sequencing of the treated PCR products was performed using the corresponding forward primer and Big Dye 3.1 reagent mix (Applied Biosystems, Life Technologies, NY, USA). Sequence data were analyzed using Sequencher 5.2 software (GeneCodes Corp, $\mathrm{MI}, \mathrm{USA}$ ) and confirmed to represent the gene of interest by comparing the PCR product sequence to the known genetic sequence of the AMR gene of interest using the BLAST sequence analysis tool (https://blast.ncbi.nlm.nih.gov/Blast.cgi). Samples were considered positive for vanA or vanB if they had both PCR product size consistent with the gene of interest and the PCR sequence was confirmed to match that of the gene of interest.

Table 2: Primers used for PCR analyses 


\begin{tabular}{|l|l|l|}
\hline Primers & Nucleotide Sequence (5'-3') & Size of PCR Product (bp) \\
\hline $16 S$ rRNA & $\begin{array}{l}\text { Forward: TGCCAGCAGCCGCGGTA (516f) } \\
\text { Reverse: GGTTACCTTGTTACGACTT (1510r) }\end{array}$ & 994 \\
\hline ent $^{13}$ & $\begin{array}{l}\text { Forward: TACTGACAAACCATTCATGATG } \\
\text { Reverse: AACTTCGTCACCAACGCGAAC }\end{array}$ & 112 \\
\hline vanA $^{14}$ & $\begin{array}{l}\text { Forward: AATACTGTTTGGGGGTTGCTC' } \\
\text { Reverse: CTTTTTCCGGCTCGACTTCCT }\end{array}$ & 734 \\
\hline vanB $^{14}$ & $\begin{array}{l}\text { Forward: GCGGGGAGGATGGTGGGATAGAG } \\
\text { Reverse: GGAAGATACCGTGGCTCAAAC }\end{array}$ & 420 \\
\hline
\end{tabular}

\section{Results}

VanA and vanB PCRs were successfully validated using the positive control isolates. Of the 40 products tested, all had evidence of bacterial DNA by 16S rRNA PCR. All the products claimed to contain at least one Enterococcus spp. on the label, however four of these products did not have evidence of Enterococcus spp. DNA based on this PCR, as shown in Table 1. The samples that did not have evidence of enterococcal DNA did not have vanA and vanB PCRs performed. Two probiotics had a PCR product consistent with vanA which was subsequently confirmed by sequencing. None of the products had PCR product consistent with vanB.

\section{Discussion}

The AMR gene vanA was identified in 2 of the 36 products that contained Enterococcus spp DNA in this study. None of the products contained $v a n B$. Despite the relatively low incidence of detecting of $v a n A$ in these probiotics, given the public health significance of vancomycin resistance and the unregulated use of these products, we believe that these results are noteworthy.

Van $A$ and $\operatorname{van} B$ are the most prevalent vancomycin resistant variants in VRE $[15,16]$. Consistent with the results from this study, vanA is more prevalent than van $B$ in food samples, which is likely due to increased mobility of the vanA gene cluster compared to $\operatorname{van} B[17,18]$. Phenotypically, vanA is responsible for both a high level of resistance to vancomycin and teicoplanin [18]; both of which are considered medically important for use in resistant infections or in individuals allergic to $\beta$-lactams [19]. Furthermore, in addition to horizontal transfer to other Enterococcus spp., vanA has also been demonstrated to transfer to Staphylococcus spp. [20-23]. Thus, the identification of mobile elements conferring vancomycin resistance used in products that are marketed for use in companion animals (dogs) which live in close proximity with people and in minor food animal species (goats) is concerning.

Food products have been identified as a possible route for transfer of resistant Enterococcus spp. from animals to people [24-27] and the risk of transmitting VRE from animals to humans has been cited as a public health concern [28]. Probiotics are becoming increasingly popular in humans and animals stemming from a desire for more "natural" treatments, to decrease the use of antimicrobials and to improve gastrointestinal health $[29,30]$. Given the nature that probiotics are administered - either in a 
daily fashion to prevent disease or in a daily fashion during intestinal disease - the presence of vanA is potentially concerning. In Europe, the food chain has been suspected to be a source of VRE acquired by humans [28] and the European Food Safety Authority has stated that commercial probiotics must establish their lack of acquired or transferrable resistance factors in order to be declared safe for human and animal consumption [31]. To date, similar requirements have not been implemented in the United States.

Interestingly, of the 40 products that claimed to contain Enterococcus spp. on the product label, only 36 had evidence of Enterococcus spp. DNA. These potential differences between the label claims and actual contents may supports previous studies that have repeatedly established discrepancies between label claims and viable micro-organisms in probiotics marketed for use in animals [30,32]. Probiotics are typically considered "Generally Recognized as Safe" or GRAS in the United States by the Food and Drug Administration and typically do not undergo post-processing scrutiny or quality control. However, products containing Enterococcus spp. have been a source of debate in both the United States and Europe and do not automatically earn classification as GRAS in the US. However, several strains of Enterococcus faecium have been approved by the FDA for use in probiotics. The results from this study would suggest that further scrutiny is necessary. It is possible that strains that were once free AMR genes in starter cultures subsequently acquired such mobile elements and no longer represent the originally approved strain [33].

In conclusion, here we report identifying vanA, a known transferrable vancomycin resistant gene, in 2 of 36 commercially available probiotics marketed for use in animals which also contained Enterococcus spp. DNA. Given the public health significance of vancomycin resistance, the established transferable nature of vanA between Enterococcus spp. and other bacterial species and the growing popularity of probiotics we believe that these results warrant consideration.

\section{Limitations}

There are several weaknesses of this study worth consideration. First, the identification of the vanA gene was determined using molecular based techniques, thus it is possible that despite results indicating the presence of vanA genes within these products, the bacteria would not be phenotypically consistent with vancomycin and teicoplanin resistant species. Such organisms have been reported rarely [34-36], however work by Gouisia and colleagues indicate that almost all Enterococcus spp. carrying vanA express corresponding resistance [17]. Second, the presence or absence of Enterococcus spp. was not confirmed by culture. Thus, it is possible that some of the products without Enterococcus spp. DNA had viable Enterococcus spp. that were not identified by the PCR due to low levels or other inhibiting factors. Likewise, it is possible that some products with Enterococcus spp. DNA identified by PCR did not have viable Enterococcus spp, and DNA from dead micro-organisms were amplified. Third, the results of this study are qualitative in nature (presence of absence of the gene) and not quantitative. Thus, although we identified the presence of vanA genes in veterinary probiotics, the quantity of genetic material per dose of probiotic was not measured and was beyond the scope of this work. Quantitative information may be 
valuable when determining the risk of conferring vanA resistance. Finally, given the lack of microbial culture data in this study, we were unable to determine which bacterial species contained the vanA gene. Further investigation is warranted to culture the bacteria in these products and determine MIC values for vancomycin to determine which bacteria have phenotypic resistance to vancomycin.

\section{List Of Abbreviations}

Antimicrobial resistance

Polymerase-chain reaction

United States of America

Vancomycin resistant Enterococcus
AMR

PCR

USA

VRE

\section{Declarations}

Ethics Approval and consent to participate: Not Applicable

Consent for Publication: Not Applicable

Availability of Data and Materials: The datasets used and/or analyzed during the current study are available from the corresponding author on reasonable request.

Competing Interests: The authors declare that they have no competing interests

Funding: This project was funded by Washington State University College of Veterinary Medicine's Intramural Grant Funds.

Author Contributions: $\mathrm{AB}, \mathrm{RB}$ and JK all contributed to study design, data acquisition, data interpretation and writing of the manuscript. All authors read and approved the final manuscript.

Acknowledgements: Not Applicable

\section{References}

1. Doi Y, Passet V, Verhoef J, Grimot PA, Brisse S. Multilocus sequence typing of Klebsiella pneumonia nosocomial isolates. J Clin Microbiol. 2017;43:4178-82.

2. Silbergeld EK, Graham J, Price LB. Industrial food animal production, antimicrobial resistance, and human health. Annu. Rev. Public Health. 2008;29:151-69.

3. Rice LB. Emergency of vancomycin-resistant enterococci. Emerg Infect Dis. 2001;7:183-7.

4. Courvalin, P. Vancomycin resistance in gram-positive cocci. Clin Infect Dis. 2006;42:S25-34. 
5. Kristich CJ, Rice LB, Arias CA. Enterococcal infection-treatment and antibiotic resistance. In: Gilmore, MS, Clewell DB, Ike Y, Shankar N, editors. Enterococci: From Commensals to Leading Causes of Drug Resistant Infection, Boston.

6. Hill C, Guarner F, Reid G, Gibson GR, Merenstein, DJ, Pot B, Morelli L, Canani RB, Flint HJ, Salminen S, Calder PC, Sanders ME. The International Scientific Association for Probiotics and Prebiotics consensus statement on the scope and appropriate use of the term probiotic. Nat. Rev. Gastro Hepat. 2014;11:506-14.

7. Mathur S, Singh R. Antibiotic resistance in food lactic acid bacteria-a review. Int J Food Microbiol. 2005; 105(3): 281-95.

8. Tarasova E, Yermolenko E, Donets V, Sundukova M, Bochkareva A, Borschev I, Suvorova M, llyasov I, Simanenkov $V$ and Suvorov A. The influence of probiotic Enterococcus faecium strain L5 on the microbiota and cytokines expression in rats with dysbiosis induced by antibiotics. Benef Micobes. 2010;1:265-70.

9. Molina MA, Diaz AM, Hesse C, Ginter W, Gentilini MV, Nunez GG, Canellada AM, Sparwasser T, Berod L, Castro MS, Manghi MA. Immunostimulatory effects triggered by Enterococcus faecalis CECT7121 probiotic strain involve activation of dendritic cells and interferon-gamma production. PLOS ONE. 2015;10:

10. Clewell DB. Movable genetic elements and antibiotic resistance in enterococci. Eur J Clin Microbiol Infect Dis 1990;9:90-102.

11. Gilmore MS, Clewell DB, Ike Y, et al. eds. Enterococci: From Commensals to Leading Causes of Drug Resistant Infection. Boston: Massachusetts Eye and Ear Infirmary; 2014.

12. Nagashima K, Hisada $T$, Sato $M$, et al. Application of new primer-enzyme combinations to terminal restriction fragment length polymorphism profiling of bacterial populations in human feces. Appl Environ Microbiol. 2003;69:1251-62.

13. Ke D, Picard FJ, Martineau F, et al. Development of a PCR assay for rapid detection of enterococci. J Clin Microbiol 1999;37:3497-3503.

14. Khan SA, Nawaz MS, Khan AA, et al. Molecular characterization of multidrug-resistant Enterococcus spp. from poultry and dairy farms: detection of virulence and vancomycin resistance gene markers by PCR. Mol Cell Probes 2005;19:27-34.

15. Holknect BJ, Hansen DS, Nielsen L, Kailow A, Jarløv JO. Screening for vancomycin-resistant enterococci with Xpert ${ }^{\circledR} v a n A / v a n B$ : diagnostic accuracy and impact on infection control decision making. New Microbes New Infect 2017; 16:54-9.

16. Werner G, Klare I, Fleige C, Geringer U, Witte W, Just HM, Ziegler R. Vanocmycin-resistant vanB-type Enterococcus faecium isolates expressing varying levels of vancomycin resistance and being highly prevalent among neonatal patients in a single ICU. Antimicrob Resist Infect Control. 2012;1:21.

17. Gousia P, Economou V, Pozidis P, Papadopoulou C. Vancomycin Resistance Phenotypes, Vancomycin-Resistance Genes and Resistance to Antibiotics of Enterococci Isolated from Food of Animal Origin. Foodborne Pathogens and Disease. 2015;12:214-220. 
18. Corso AC, Gagetti PS, Rodriguez MM, Melano RG, Ceriana PG, Faccone DF, Gallas M. Molecular epidemiology of vancomycin-resistant Enterococcus faecium in Argentina. Int J Infec Dis 2007;11:69-71.

19. Courvalin P. Vancomycin resistance in Gram positive cocci. Clin Infect Dis. 2006;42:S25-34.

20. Centers for Disease Control and Prevention Vancomycin-resistant Staphylococcus aureus-New York, 2004. MMWR Morb Mortal Wkly Rep. 2004;53:322-23

21. Chang S, Sievert DM, Hageman JC, Boulton ML, Tenover FC, Downes FP, Shah S, Rudrik J, Pupp G, Brown WJ, Cardo D, Fridkin SK. Infection with vancomycin-resistant Staphylococcus aureuscontaining the vanA resistance gene. N Engl J Med. 2003;348:1342-47.

22. Tenover FC, Weigel LM, Appelbaum PC, McDougal LK, Chaitram J, McAllister S, Clark N, Killgore G, O’Hara CM, Jevitt L, Patel JB, Bozdogan B. Vancomycin-resistant Staphylococcus aureusisolate from a patient in Pennsylvania. Antimicrob Agents Chemother. 2004;48:275-80.

23. Weigel LM, Clewell DB, Gill SR, Clark NC, McDougal LK, Flannagan SE, Kolonay JF, Shetty J, Killgore GE, Tenover FC. Genetic analysis of a high-level vancomycin-resistant isolate of Staphylococcus aureus. Science. 2003;302:1569-71.

24. Lester CH, Frimodt-Møller N, Lund Sørensen T, Monnet DL, Hammerum AM. In vivo transfer of the vanA resistance gene from an Enterococcus faecium isolate of animal origin to an faecium isolate of human origin in the intestines of human volunteers. Antimicrob Agents Chemother. 2006;50:596-99.

25. Vignaroli C, Zandri G, Aquilanti L, Pasquaroli S, Biavasco F. Multidrug-resistant enterococci in animal meat and faeces and co-transfer of resistance from an Enterococcus durans to a human Enterococcus faecium. Curr Microbiol 2011;62:1438-47.

26. Sparo M, Urbizu L, Solana MV, Pourcel G, Delpech G, Confalonieri A, Ceci M, Sanchez Bruni SF. Highlevel resistance to gentamicin: Genetic transfer between Enterococcus faecalis isolated from food of animal origin and human microbiota. Lett Appl Microbiol 2012;54:119-25.

27. Klibi N, Said LB, Jouini A, Slama KB, Lopez M, Sallem RB, Boudabous A, Torres C. Species distribution, antibiotic resistance and virulence traits in enterococci from meat in Tunisia. Meat Sci 2013;93:675-80.

28. Robredo B, Singh KV, Baquero F, Murray BE, Torres C. Vancomycin-resistant enterococci isolated from animals and food. Int J Food Microbiol. 2000;54:197-204.

29. Weese JS, Anderson ME, Lowe A, Monteith GJ. Preliminary investigation of the probiotic potential of Lactobacillus rhamnosus strain GG in horses: fecal recovery following oral administration and safety. Can Vet J. 2003;44:299-302.

30. Weese JS and Martin H. Assessment of commercial probiotic bacterial contents and label accuracy. Can Vet J. 2011;52:43-6.

31. Ricci A, Allende A, Bolton D, Chemaly M, Davies R, Girones R, Herman L, Koutsoumanis K, Lidqvist R, Nørrung B, Robertson L, Ru G, Sanaa M, Simmons M, Skandamis P, Snary E, Speybroeck N, Kuile B, Threlfall J, Wahlstrom H, Cocconcelli PS, Klein G, Maradona M, Querol A, Peize L, Suarez J, Sundh I, Vlak JM, Aguilera-Gomez M, Barizzone F, Brozzi R, Correia S, Heng L, Istace F, Lythgo C, Escamez P. 
Scientific opinion on the maintenance of the list of QPS biological agents intentionally added to food and feed. EFSA Journal 2012;10:3020.

32. Weese JS. Microbiologic evaluation of commercial probiotics. JAVMA. 2002;220:794-7

33. Braiek OB and Smaoi S. Enterococci: Between Emerging Pathogens and Potential Probiotics. Biomed Res Int 2019;

34. Huh JY, Lee WG, Lee K, Shin WS, Yoo JH. Distribution of insertion sequences associated with Tn1546-like elements among Enterococcus faecium isolates from patients in Korea. J Clin Microbiol Newslett 2013;35:45-51.

35. Naas T, Fortineau N, Snanoudj R, Spicq C, Durrbach A, Nordmann P. First nosocomial outbreak of vancomycin-resistant Enterococcus faecium expressing a vanD-like phenotype associated with a vanA J Clin Microbiol 2005;43:3642-9.

36. Chan YY, Abd Nasir MH, Rahaya MA, Salleh NM, Md Dan AD, Musa AM, Ravichandran M. Low prevalence of vancomycin-and bifunctional aminoglycoside-resistant enterococci isolated from poultry farms in Malaysia. Int J Food Microbiol 2008;122:221-6. 